\title{
Self - Organizing Teams in Software Development - Myth or Reality
}

\author{
Tarik Zaimovic ${ }^{1}$, Muharem Kozic ${ }^{2}$, Amina Efendić ${ }^{1}$, Amel Džanić ${ }^{3}$ \\ ${ }^{I}$ School of Economics and Business Sarajevo, University of Sarajevo, Sarajevo, Bosnia and Herzegovina \\ ${ }^{2}$ Faculty of Economy, "Džemal Bijedić" University of Mostar, Mostar, Bosnia and Herzegovina \\ ${ }^{3}$ Faculty of Technical Engineering Bihać, University of Bihać, Bihać, Bosnia and Herzegovina
}

\begin{abstract}
In an agile business environment, teamwork quality is underlining key element of successful projects and overall team performance. In the Scrum framework, self-managing team is a central element of success. Self-managing teams introduced a new concept of teams and emphasized the importance of individual member effort and the way it affects team performance. The focus of this paper is on teamwork quality in self-managing teams and the way it affects the overall team performance. Teamwork quality is defined by six subconstructs: communication, coordination, balance of member contributions, mutual support, effort, and cohesion, while team performance is defined with effectiveness and efficiency. A survey of 260 respondents from the IT sector in Bosnia and Herzegovina was conducted and in both tested models, our results have confirmed that the highest effect on team effectiveness comes from mutual support, with slightly different - but still significant, impact of team cohesion and effort.
\end{abstract}

Keywords - agile methods, agile team, teamwork quality, team performance, self-managing teams

DOI: $10.18421 /$ TEM104-10

https://doi.org/10.18421/TEM104-10

Corresponding author: Muharem Kozić,

Faculty of Economy, "Džemal Bijedić" University of Mostar, Mostar, Bosnia and Herzegovina.

Email: muharem.kozic@unmo.ba

Received: 13 August 2021.

Revised: 22 September 2021.

Accepted: 01 October 2021.

Published: 26 November 2021.

(cc) BY-NC-ND (C) 2021 Tarik Zaimovic et al; published by UIKTEN. This work is licensed under the Creative Commons Attribution-NonCommercial-NoDerivs 4.0 License.

The article is published with Open Access at www.temjournal.com

\section{Introduction}

Companies in the IT sector most often develop their products and services by using two models: plan-driven (traditional) and agile. The agile model has becoming increasingly dominant in the last two decades; specifically, the Scrum method is the most often used agile method.

The agile model is based on the concept of selfmanaging teams; however, the possibility of selfmanaging agile teams to succeed has not been explored enough [1]. On the other hand, within the traditional software development, there are available researches on the effects of team quality on the project success [2], [5]. Authors Lindsjørn, Sjøberg, Dingsøyr, Bergersen and Tore Dybå researched the effect of teamwork quality on team performance, learning and work satisfaction in agile teams in IT companies. They also study whether this effect is different from that of traditional teams in IT companies. According to the research results, teamwork quality significantly affects team performance, and the results have not shown significant oscillations when compared with traditional teams. As Scrum is the most often used agile method, there is a question how development teams function in practice by following the characteristics of self-management.

\section{Agile Software Development Methods}

For more than a half of decade, software has been part of everyday personal and business life. Organizations had to adapt to continuous and fast market changes, and most often, unstable business environments. To survive in a modern environment, organizations had to become agile. Today, the ability to be agile is not an option; it is a condition for being part of the market [3].

In order to deal with the disadvantages of traditional methods, agile methods are created [4]. The main characteristic of agile software development provides a way to organize complex multi-participant software development while 
accommodating constant project change [6]. The use of agile methods affects organizational structure, culture, and employees. It affects the way clients are involved in the development process and it affects the project quality in total [6]. Flexibility and responsiveness are the main characteristics for companies applying agile methods, which is crucial in a modern business environment [4]. In agile methods, team members and high satisfaction of customers' requests are the focus [7]. The most popular agile methods are Dynamic Systems Development Method, Feature Driven Development, Extreme Programming, Lean Development, Crystal, Adaptive Software Development, Kanban, Scrum and hybrid methods [8] [9] [10]. As an answer to business environment changes and availability of agile methods, hybrid methods have emerged and as a result we have Leanban and Scrumban methods.

In 2001, 17 experts signed the Agile Manifesto and founded the Agile Alliance organization. The document is defining the meaning of agile software development [4]. The Manifesto promotes: individuals and interactions over processes and tools; working software over comprehensive documentation; customer collaboration over contract negotiation and responding to change over following a plan [11], [6], [12].

Scrum is the most popular and most often used agile framework. It includes Scrum team, Scrum events, Scrum artifacts, and rules that bind them together. Product Owner, Scrum Master and Development team are part of a Scrum team. Scrum events are: Sprint, Sprint Planning, Daily Scrum, Sprint Review and Sprint Retrospective. Product Backlog, Sprint Backlog and Increment are Scrum Artifacts.

\section{Teamwork Quality and Team Performance}

Teamwork quality is defined with six subconstructs: communication, coordination, balance of member contributions, mutual support, effort, and cohesion.

Communication - There are various ways to describe the quality of communication, which includes frequency, formalization, structure, and openness when exchanging information. Frequency of information sharing refers to the extent of communication within the team. The formalization means spontaneity of communication with each other. Communication requires more preparation and planning is considered more formal, while spontaneous communication is seen as more informal. Informal communication has proved crucial in innovation focused projects as this tends to create the environment for more open ideas and contributions sharing, as well as quick and efficient team' discourse [13] [2] [1]. The quality of team collaboration is also determined by the ability of team members to communicate directly, because information exchange through intermediaries (e.g., team leaders) is time-consuming and leaves room for misinterpretation and transmission of misinformation. The lack of openness in sharing information in a team (e.g., a team member does not want to share important information with the other members) impairs the fundamental functions of teamwork, i.e., impedes the exchange of knowledge and experience between team members [2], [1].

Coordination - Coordination has been described by Malone and Crowston as managing activity dependencies [14]. The dependencies relate to resource sharing, task sharing, and task/subtask relationships [1]. Teamwork quality will also determine the level of understanding the connection and the current status of individual contributions. Working together is a crucial, but still a number of activities have to be addressed individually. The coordination and synchronization of individual contributions is an important component of collaborative quality [15], [16], [17].

Balance of member contributions - Teamwork quality is also affected by the ability of all team members to contribute through knowledge and experience [18]. If they cannot contribute their ideas to discussions and the decision-making process, the purpose of cross-functional teams would be lost. Therefore, it is crucial to balance the member contributions with respect for the knowledge and experience of each member. Not all team members will contribute the same amount of ideas, but this should not preclude suggesting ideas and contributing appropriate knowledge to the team [2]. Within development teams, the contributions of team members with expertise in various fields is crucial. Any team member dominating the discussion may adversely affect the motivation of the rest of the team, which further negatively affects the teamwork results. In an agile team, daily meetings support its member contributions [1].

Mutual support - Another key factor in teamwork quality is the mutual support in the team. Here, the individual level of competitiveness plays an important role. When it comes to individual tasks, there is no doubt that competitiveness affects motivation, but mutual support in the team has a greater impact on productivity. Teams working toward a common goal should show more mutual support and help when needed and discuss and develop ideas of other team members rather than try to minimize them [2], [1].

Effort - Teams define shared expectations regarding the behaviour of their members [19]. Defined shared expectations in the context of the 
member effort are particularly important for teamwork quality. Dividing and prioritizing team tasks over other team responsibilities is crucial. To achieve a high teamwork quality and avoid internal conflicts it is important that every member knows and accepts the defined common expectations regarding the member effort. Equally high is the key to quality collaboration efforts of all team members [2]. In agile teams, achieving better effectiveness and performance of teamwork often resides in putting collective tasks ahead.

Cohesion - Team cohesion refers to the level of desire to be part of the team and work together to achieve the defined goals [1]. Three aspects of cohesion have been defined: the interpersonal connection in the team, dedication to the accomplishment of the tasks and the existence of team spirit [2], [1]. A high level of teamwork quality requires adequate cohesion. Without a sense of belonging there will ultimately be no collaboration.

Effectiveness and Efficiency - Team performance is measured through the team's effectiveness and efficiency and can be regarded as the team ability to achieve the defined quality while working within the planned costs and set time frames [1], [2]. Efficiency refers to the ability of the team to achieve the expected quality of the product. The quality of the software is measured through the functionality, robustness, reliability, and performance of the system. Efficiency means the team ability to achieve the expected project quality (budget and time).

\section{Research Method}

Having in mind the defined problem and the research subject, purpose, and the research made for this paper, the main hypothesis has been postulated:

There is a positive relation between self-managing teams and total team performance.

For this purpose, a questionnaire shown in Table 1 was made with questions relating only to the variables of teamwork quality and team performance. The questionnaire was created on the basis of the existing researches focusing on agile teams [1], [2].

The questionnaire consisted of 61 questions. Its first part identifies the respondent characteristics: sex, age, level of education, the industry of the company they work in, the length of work there, which agile method they use and do they use it at least one year, and finally, the role assigned to them within the team. In this first part, the respondents chose the role they perform within their team: Team Leader, Product Owner, or Development Team Member.
Table 1. Questions and variables

\begin{tabular}{|c|c|}
\hline Question & $\begin{array}{c}\text { Variable/ } \\
\text { abbreviation }\end{array}$ \\
\hline $\begin{array}{l}\text { 1. Communication among team members is } \\
\text { often. }\end{array}$ & \multirow{10}{*}{ 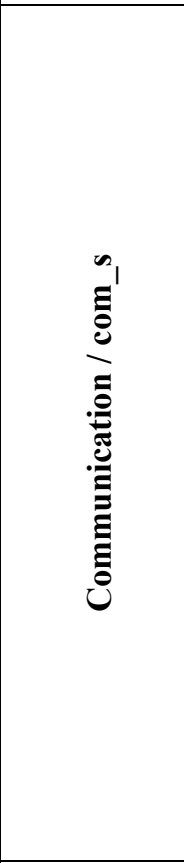 } \\
\hline $\begin{array}{l}\text { 2. Team members often communicate in } \\
\text { unplanned meetings, over the phone, etc. }\end{array}$ & \\
\hline $\begin{array}{l}\text { 3. Team members most often communicate } \\
\text { directly. }\end{array}$ & \\
\hline $\begin{array}{l}\text { 4. There are mediators through which } \\
\text { communication takes place. }\end{array}$ & \\
\hline $\begin{array}{l}\text { 5. Team members openly share relevant } \\
\text { ideas and information. }\end{array}$ & \\
\hline $\begin{array}{l}\text { 6. In some situations, important information } \\
\text { is not shared }\end{array}$ & \\
\hline $\begin{array}{l}\text { 7. Conflicts in the team arise because of lack } \\
\text { of information. }\end{array}$ & \\
\hline $\begin{array}{l}8 . \text { Team members timely share information } \\
\text { received from the other members. }\end{array}$ & \\
\hline $\begin{array}{l}\text { 9. Team members are satisfied with the } \\
\text { accuracy of information received from the } \\
\text { other members. }\end{array}$ & \\
\hline $\begin{array}{l}\text { 10. Information shared within the team is } \\
\text { useful and specific. }\end{array}$ & \\
\hline $\begin{array}{l}\text { 11. Team members' activities carried out } \\
\text { within subtasks are coordinated. }\end{array}$ & \multirow{4}{*}{ 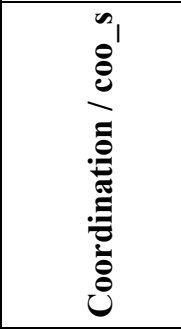 } \\
\hline $\begin{array}{l}\text { 12. Team has defined clear goals for } \\
\text { subtasks. }\end{array}$ & \\
\hline $\begin{array}{l}\text { 13. All team members have adopted the } \\
\text { defined goals of subtasks. }\end{array}$ & \\
\hline $\begin{array}{l}\text { 14. There are conflicts of interest in the } \\
\text { team regarding subtasks/subgoals. }\end{array}$ & \\
\hline $\begin{array}{l}\text { 15. Team members assist and support each } \\
\text { other. }\end{array}$ & \multirow{7}{*}{ 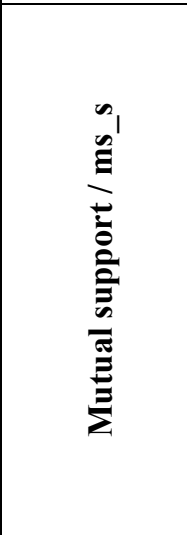 } \\
\hline $\begin{array}{l}\text { 16. Conflicts are resolved simply and } \\
\text { quickly. }\end{array}$ & \\
\hline 17. Discussions are constructive. & \\
\hline $\begin{array}{l}\text { 18. Team respects individual suggestions } \\
\text { and contributions. }\end{array}$ & \\
\hline $\begin{array}{l}\text { 19. Team considers and elaborates } \\
\text { individual suggestions and contributions. }\end{array}$ & \\
\hline $\begin{array}{l}\text { 20. Team is able to agree on important } \\
\text { questions. }\end{array}$ & \\
\hline $\begin{array}{l}21 . \text { Internal cooperation in the team is } \\
\text { satisfactory. }\end{array}$ & \\
\hline $\begin{array}{l}\text { 22. Every team member fully supports } \\
\text { teamwork. }\end{array}$ & \multirow{4}{*}{ 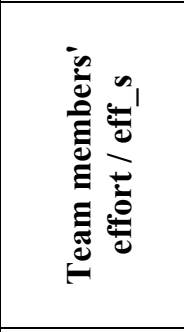 } \\
\hline $\begin{array}{l}\text { 23. Teamwork is a priority for its every } \\
\text { member. }\end{array}$ & \\
\hline $\begin{array}{l}\text { 24. Team invests a lot of effort into } \\
\text { teamwork. }\end{array}$ & \\
\hline $\begin{array}{l}\text { 25. Conflicts arise about the invested } \\
\text { individual effort into teamwork. }\end{array}$ & \\
\hline 26. Team considers teamwork important. & \multirow{5}{*}{ 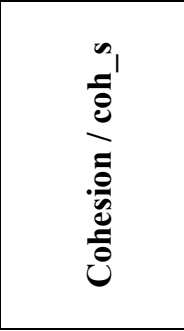 } \\
\hline $\begin{array}{l}\text { 27. Team members find it important to be } \\
\text { part of the team. }\end{array}$ & \\
\hline $\begin{array}{l}\text { 28. Team does not consider teamwork } \\
\text { necessary. }\end{array}$ & \\
\hline $\begin{array}{l}\text { 29. Individual affiliation with the team is } \\
\text { strong. }\end{array}$ & \\
\hline 30. There is full team integration of all its & \\
\hline
\end{tabular}




\begin{tabular}{|l|}
\hline members \\
\hline $\begin{array}{l}\text { 31. A lot of conflicts arise between team } \\
\text { members. }\end{array}$ \\
\hline $\begin{array}{l}\text { 32. Understanding and empathy between } \\
\text { team members are developed. }\end{array}$ \\
\hline 33. Team members hold together. \\
\hline $\begin{array}{l}\text { 34. Team members feel proud fore being } \\
\text { part of the team. }\end{array}$ \\
\hline $\begin{array}{l}\text { 35. There is individual team member } \\
\text { responsibility for the team. }\end{array}$ \\
\hline $\begin{array}{l}\text { 36. Team recognizes specific characteristics } \\
\text { of all its members individually (strengths } \\
\text { and weaknesses). }\end{array}$ \\
\hline $\begin{array}{l}\text { 37. Team members contribute to achieving } \\
\text { team goals in accordance with their } \\
\text { respective abilities. }\end{array}$ \\
\hline $\begin{array}{l}\text { 38. Imbalance in the member contributions } \\
\text { causes conflicts in the team. }\end{array}$ \\
\hline $\begin{array}{l}\text { 39. Looking at the results, teamwork may be } \\
\text { qualified as successful. }\end{array}$ \\
\hline 40. All client's requests have been fulfilled. \\
\hline $\begin{array}{l}\text { 41. The company believes that all team } \\
\text { goals have been achieved. }\end{array}$ \\
\hline $\begin{array}{l}\text { 42. Team's good performance and results } \\
\text { contribute to a greater client's satisfaction. }\end{array}$ \\
\hline 43. The result of teamwork is a quality one. \\
\hline $\begin{array}{l}\text { 44. Client values the quality of the final } \\
\text { teamwork product. }\end{array}$ \\
\hline $\begin{array}{l}\text { 45. Teamwork results give satisfaction to } \\
\text { the team. }\end{array}$ \\
\hline 46. Team product needs minimum changes. \\
\hline 47. Product is stable. \\
\hline 48. Product is robust. \\
\hline $\begin{array}{l}\text { 49. Company is satisfied with teamwork } \\
\text { progress. }\end{array}$ \\
\hline 50. Team operates cost-efficiently. \\
\hline 51. Team operates time-efficiently. \\
\hline 52. Team works under the planned schedule. \\
\hline 53. Team works within the planed budget. \\
\hline
\end{tabular}

The next part of the questionnaire focuses on researching the variables of teamwork quality and team performance. Within the research, the observed unit was team members individually while that unit in references [1], [2] was team.

\subsection{Factor Analysis}

After receiving the answers, the suitability of the received data for a factor analysis was verified, using the package factor test of the STAT software tool.

The Kaiser-Meyer-Olkin measure indicates the sampling adequacy. It is 0.818 , which leads to the conclusion that the correlation matrix is suitable for a factor analysis. Bartlett's test of sphericity X2(105) $=332.8, \mathrm{p}=0.000$ is significant, so we may conclude that there is a correlation among the observed variables in the population. The correlation matrix determinant is 0.193 and it is higher than 0.00001 , which indicates that there is no extreme multicollinearity within the data, so the conclusion from the above is that the obtained data are appropriate for an explorative factor analysis, which can be seen in Figure 1.

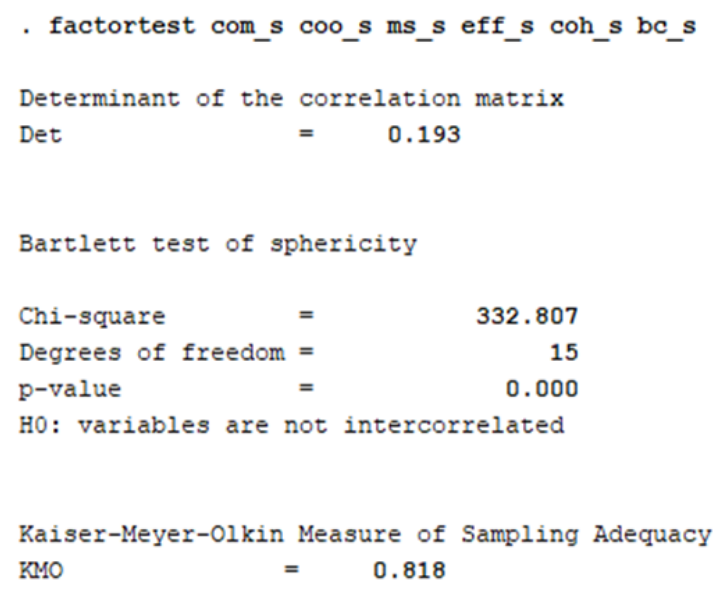

Figure 1. Assessment of data suitability

To determine the optimal number of factors, the Kaiser criterion, or K1 criterion or latent root criterion was used. According to it, all factors with characteristic value higher than 1 should be kept. Six indicator variables were initially analysed using the principal component factoring estimation method. Based on the Kaiser criterion, one factor, the characteristic value of which is $>1$, was retained, which is shown in Figure 2.

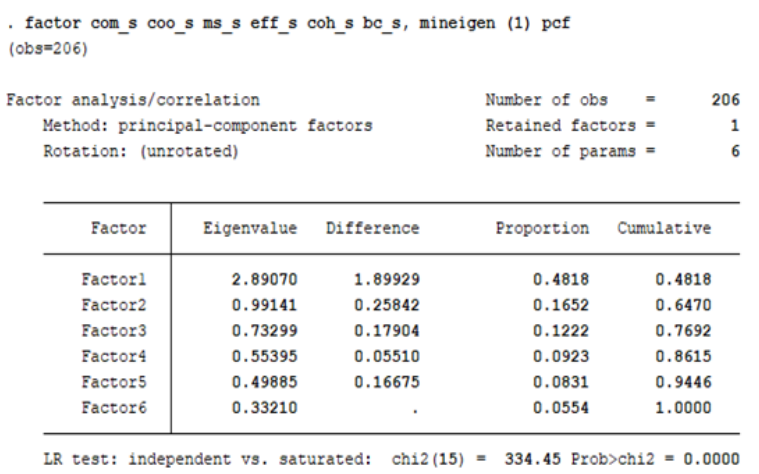

Factor loadings (pattern matrix) and unique variances

\begin{tabular}{r|r|r}
\hline Variable & Factorl & Uniqueness \\
\hline com_s & 0.2769 & 0.9233 \\
coo_s & 0.6968 & 0.5145 \\
ms_s & 0.7472 & 0.4416 \\
eff_s & 0.7893 & 0.3771 \\
coh_s & 0.8613 & 0.2581 \\
bc_s & 0.6366 & 0.5947 \\
\hline
\end{tabular}

Figure 2. Factor loadings (pattern matrix) and unique variances 


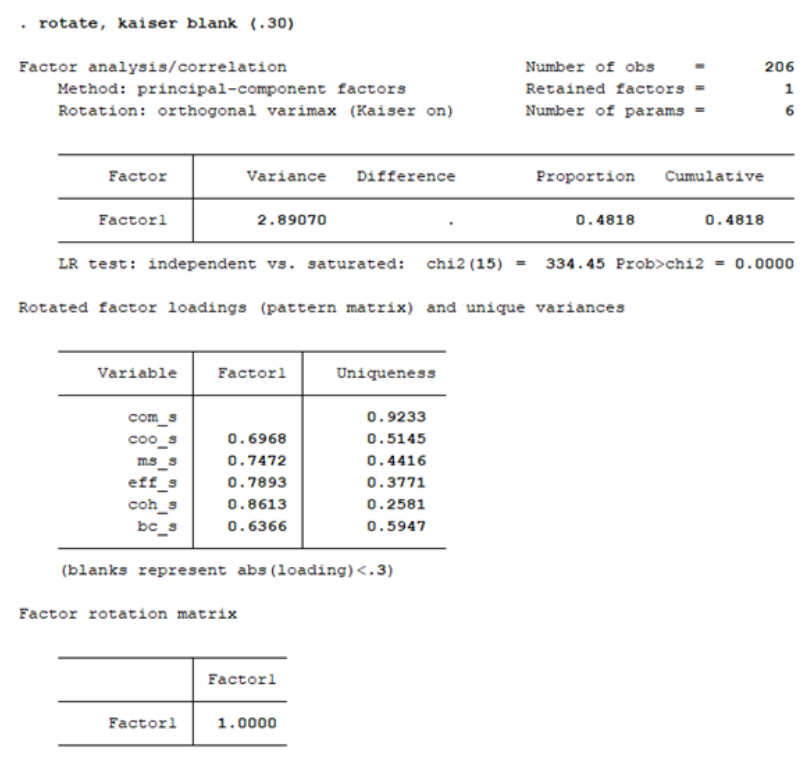

Figure 3. Varimax rotation with the Kaiser normalization

After completing the factor analysis, the internal consistency of the scale was verified by calculating Cronbah's alfa coefficient for Elements of teamwork, and it is 0.8032 , hence leading to the conclusion that the scale used for measuring the factor has a good reliability. Elements of teamwork consists of the variables of coordination, mutual support, effort, cohesion, and contributions, in which the cohesion variable has the greatest effect.

\subsection{Regression Analysis}

Regression analysis is a statistical technique for modelling the relationship between a dependent variable and one or more independent variables.

Figure 4 shows the data for eight variables. The summary variables have been obtained by averaging the answers to the questions composing them. The results suggest that the respondents rated communication with 3.97 ; coordination with 3.58 ; mutual support with 4.27 ; effort with 3.72 ; cohesion with 3.58; contributions with 3.59 ; effectiveness with 4,61 , and efficiency with 4,68 . The minimal grade for communication was 2.6 , coordination 2.25 , mutual support 2.43, effort 2, cohesion 2.4, contributions 2, effectiveness 1, and efficiency 1 . On average, the highest grade was 5 for all variables, except communication whose highest grade was 4.9.

\begin{tabular}{|c|c|c|c|c|c|}
\hline Variable & $\mathrm{obs}$ & Mean & Std. Dev. & Min & $\operatorname{Max}$ \\
\hline com_s & 206 & 3.970388 & .4574018 & 2.6 & 4.9 \\
\hline $\mathrm{COO}_{-}^{-} \mathrm{s}$ & 206 & 3.581311 & .5124096 & 2.25 & 5 \\
\hline $\mathrm{ms}_{-}^{-} \mathrm{s}$ & 206 & 4.273925 & .5861855 & 2.428571 & 5 \\
\hline eff_s & 206 & 3.723301 & .5842575 & 2 & 5 \\
\hline $\mathrm{coh}_{-} \mathrm{s}$ & 206 & 3.587864 & .4904933 & 2.4 & 5 \\
\hline$b c_{-} s$ & 206 & 3.587379 & .53361 & 2 & 5 \\
\hline $\mathrm{efe}_{-}^{-} \mathrm{s}$ & 206 & 4.605825 & .6825812 & 1 & 5 \\
\hline efi_s & 206 & 4.681553 & .7185008 & 1 & 5 \\
\hline
\end{tabular}

Figure 4. Descriptive statistics for the eight observed variables
The next step was assessing the parameters of the model describing the effect of teamwork quality variable on team performance. The effects of teamwork quality were observed separately for effectiveness (model 1) and efficiency (model 2).

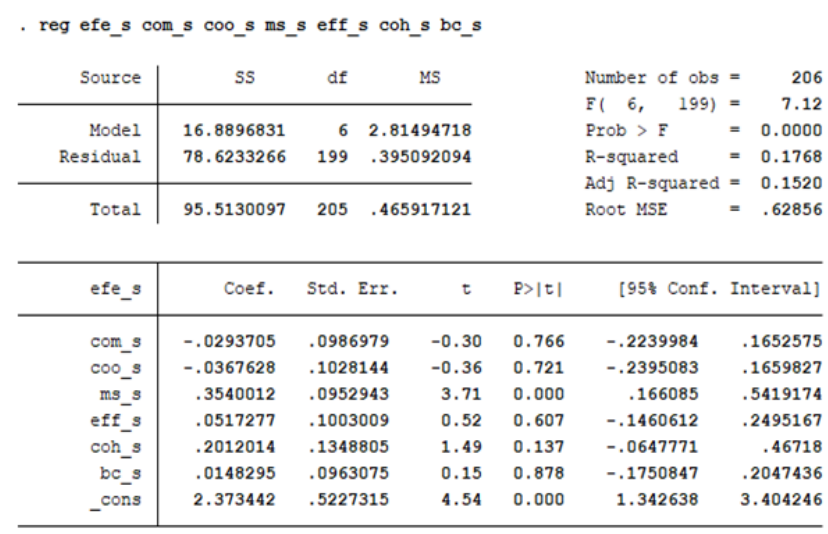

Figure 5. Assessment of regression model for effectiveness - model 1

Figure 5 shows the effect of the variables on effectiveness. The adjusted coefficient of determination is $\mathrm{R} 2=0.1520$, indicating that $15.2 \%$ of the variance for the effectiveness variable is explained by the included variables. The value of positive regression coefficients indicates a positive relationship between the dependent variable and the independent variables. The coefficient also shows how each predictor affects the dependent variable provided that the effect of all other predictors does not change.

The obtained coefficients have an associated standard error indicating to which extent their values would vary among different samples. If the t-test value of the associated coefficient of significance is less than 0.05 , i.e., if the value in the column $P>|t|$ is less than 0.05), then the predictor significantly contributes to predicting the value of the dependent variable. The higher the value of t-statistics, the higher the contribution of the given predictor. Based on this, we may conclude that communication and coordination do not affect effectiveness. On the other hand, mutual support $(\mathrm{t}(206)=3.71, \mathrm{p}<0.01)$, effort $(\mathrm{t}(206)=0.52, \mathrm{p}<0.01)$, cohesion $(\mathrm{t}(206)=1.49, \mathrm{p}<$ $0.01)$, and contributions $(\mathrm{t}(206)=0.15, \mathrm{p}<0.01)$ significantly contribute to achieving effectiveness. Mutual support and cohesion have the highest impact on effectiveness.

Standardized regression coefficients are the coefficients obtained by standardizing all independent variables and presenting them through the $\mathrm{z}$-score. These coefficients are shown in the column Beta (figure 6). Their values indicate the number of standard deviations for which the value of the dependent variable will change if the value of an independent variable is changed for one standard deviation. 


\begin{tabular}{|c|c|c|c|c|c|c|c|}
\hline Source & SS & df & \multicolumn{2}{|c|}{ MS } & & \multirow{2}{*}{$\begin{array}{l}\text { Number of obs } \\
\text { F( 6, 199) } \\
\text { Prob }>\text { F }\end{array}$} & \multirow{2}{*}{$\begin{array}{l}=206 \\
=7.12 \\
=0.0000\end{array}$} \\
\hline Model & 16.8896831 & 62 & \multicolumn{2}{|c|}{2.81494718} & & & \\
\hline Residual & 78.6233266 & 199. & \multicolumn{2}{|c|}{.395092094} & & \multirow{2}{*}{$\begin{array}{l}\text { R-squared } \\
\text { Adj R-squared } \\
\text { Root MSE }\end{array}$} & $=0.1768$ \\
\hline Total & 95.5130097 & 205. & .4659 & 17121 & & & $=.62856$ \\
\hline efe_s & Coef. & Std. Er & $r r$. & t & $P>|t|$ & & Beta \\
\hline com_s $_{-}$ & -.0293705 & .098697 & & -0.30 & 0.766 & & -.0196813 \\
\hline $1000_{-} 3$ & -.0367628 & .102814 & & -0.36 & 0.721 & & -.0275976 \\
\hline ms_s & .3540012 & .0952943 & & 3.71 & 0.000 & & .3040083 \\
\hline eff_s & .0517277 & .100300 & & 0.52 & 0.607 & & .0442765 \\
\hline coh_s & .2012014 & .1348805 & & 1.49 & 0.137 & & .1445805 \\
\hline$b c_{-} s$ & .0148295 & .0963075 & & 0.15 & 0.878 & & .011593 \\
\hline _cons & 2.373442 & .522731 & & 4.54 & 0.000 & & 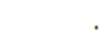 \\
\hline
\end{tabular}

Figure 6. Standardized regression coefficients for model 1

The obtained results lead to the conclusion that mutual support and cohesion have the highest relative significance within the model. The effect of these two variables is considerably higher than that of the effort and contributions variables. The communication and coordination variables have negative effects.

Figure 7 shows the effect of the variables on efficiency. The adjusted coefficient of determination is $\mathrm{R} 2=0.1443$, indicating that $14.43 \%$ of the variance of the effectiveness variable is explained by the involved variables. The value of positive regression coefficients indicates a positive relationship between the dependent variable and the independent variables. The coefficient also indicates how each predictor affects the dependent variable provided that the effect of all the other predictors does not change.

\begin{tabular}{|c|c|c|c|c|c|c|}
\hline Source & ss & df & MS & & \multirow{2}{*}{$\begin{array}{l}\text { Number of obs } \\
\text { F( } 6, \quad 199) \\
\text { Prob > F }\end{array}$} & \multirow{2}{*}{$\begin{array}{lr}= & 206 \\
= & 6.76 \\
= & 0.0000\end{array}$} \\
\hline Model & 17.9265863 & $\begin{array}{ll}6 & 2.98\end{array}$ & 2.98776438 & & & \\
\hline Residual & 87.9033166 & 199.441 & .441725209 & & $\begin{array}{l}\text { R-squared } \\
\text { Adj R-squared }\end{array}$ & $=0.1694$ \\
\hline Total & 105.829903 & $205 \quad .516$ & 43429 & & Root MSE & $=.66462$ \\
\hline efi_s & Coef. & Std. Err. & t & $P>|t|$ & [95: Conf. & Interval] \\
\hline com_s & -.1112657 & .1043602 & -1.07 & 0.288 & -.3170594 & .0945281 \\
\hline $1000^{-} s$ & -.0809107 & .1087128 & -0.74 & 0.458 & -.2952877 & .1334663 \\
\hline ms_s & .3716411 & .1007613 & 3.69 & 0.000 & .1729441 & .570338 \\
\hline eff_s & .1497517 & .1060551 & 1.41 & 0.160 & -.0593844 & .3588878 \\
\hline $\operatorname{coh}^{-} s$ & .1339611 & .1426186 & 0.94 & 0.349 & -.1472766 & .4151988 \\
\hline $\mathrm{bc}_{-} \mathrm{s}$ & -.0080813 & .1018326 & -0.08 & 0.937 & -.2088908 & .1927282 \\
\hline _cons & 2.815507 & .5527206 & 5.09 & 0.000 & 1.725566 & 3.905448 \\
\hline
\end{tabular}

Figure 7. Regression model estimate for efficiencymodel 2

Having analysed the results obtained for model 2, we may conclude that communication, coordination, and contributions do not affect efficiency. On the other hand, mutual support $(\mathrm{t}(206)=3.69, \mathrm{p}<0.01)$, effort $(\mathrm{t}(206)=1.41, \mathrm{p}<0.01)$, and cohesion $(\mathrm{t}(206)$
$=0.94, \mathrm{p}<0.333)$ significantly contribute to achieving effectiveness. Mutual support has the highest effect on efficiency.

\begin{tabular}{|c|c|c|c|c|c|c|}
\hline Source & sS & df & MS & & \multirow{2}{*}{$\begin{array}{l}\text { Number of obs }= \\
\text { F( } 6,199)= \\
\text { Prob }>\text { F }\end{array}$} & \multirow{2}{*}{$\begin{array}{l}=206 \\
=\quad 6.76 \\
=0.0000\end{array}$} \\
\hline Model & 17.9265863 & $\begin{array}{ll}6 & 2.9\end{array}$ & 76438 & & & \\
\hline Residual & 87.9033166 & 199.44 & 25209 & & R-squared & $=0.1694$ \\
\hline Total & 105.829903 & 205.51 & 43429 & & & $=0.046$ \\
\hline efi_s & Coef. & Std. Err. & $t$ & $P>|t|$ & & Beta \\
\hline com_s & -.1112657 & .1043602 & -1.07 & 0.288 & & -.0708324 \\
\hline coo_s & -.0809107 & .1087128 & -0.74 & 0.458 & & -.0577027 \\
\hline ms_s & .3716411 & .1007613 & 3.69 & 0.000 & & .3032016 \\
\hline eff_s & .1497517 & .1060551 & 1.41 & 0.160 & & .1217724 \\
\hline coh_s & .1339611 & .1426186 & 0.94 & 0.349 & & .0914502 \\
\hline bc_s & -.0080813 & .1018326 & -0.08 & 0.937 & & -.0060017 \\
\hline cons & 2.815507 & .5527206 & 5.09 & 0.000 & & . \\
\hline
\end{tabular}

Figure 8. Standardized regression coefficients for model 2

Figure 8 presents the standardized regression coefficients for model 2 . The obtained results lead to the conclusion that mutual support and effort have the highest relative significance within the model. The effect of these two variables is considerably higher than that of the cohesion variable. The communication, coordination, and effort variables have negative effects.

\section{Conclusion}

A factor and regression analysis was made with the obtained data. The factor analysis was made on six indicator variables. Using the Kaiser criterion, one factor with the characteristic value higher than 1 was kept. That factor is called Elements of teamwork and it consists of the following variables: coordination, mutual support, effort, cohesion, and contributions. The cohesion variable has the highest effect.

Within the regression analysis, we individually looked at the effects of teamwork quality on effectiveness (model 1) and efficiency (model 2).

The analysis results for model 1 have shown that the highest effect on team effectiveness comes from mutual support (std. $\beta=0.304$ ) and cohesion (std. $\beta=$ 0.1446). The effect of these two variables is significantly higher than the effect of the variables of effort (std. $\beta=0.0443$ ) and contributions (std. $\beta=$ 0.0116 ). The variables of communication (std. $\beta=-$ 0.0197 ) and coordination (std. $\beta=-0.0276$ ) have negative effect.

The analysis results for model 2 show that mutual support (std. $\beta=0.3032$ ) and effort (std. $\beta=0.1218$ ) have the highest relative significance within the model. The effect of these two variables is significantly higher than the effect of the cohesion variable (std. $\beta=0.0915$ ). The variables of 
communication (std. $\beta=-0.0708$ ), coordination (std. $\beta=-0.0577$ ) and contributions (std. $\beta=-0.006$ ) have negative effect.

The factor and regression analysis made for the purpose of this research indicates that the most significant variables affecting team performance are mutual support, cohesion, and effort while communication and coordination variables have negative effect on team performance.

\section{References}

[1]. Lindsjørn, Y., Sjøberg, D. I., Dingsøyr, T., Bergersen, G. R., \& Dybå, T. (2016). Teamwork quality and project success in software development: A survey of agile development teams. Journal of Systems and Software, 122, 274-286.

[2]. Hoegl, M., \& Gemuenden, H. G. (2001). Teamwork quality and the success of innovative projects: A theoretical concept and empirical evidence. Organization science, 12(4), 435-449.

[3]. Stoica, M., Mircea, M., \& Ghilic-Micu, B. (2013). Software Development: Agile vs. Traditional. Informatica Economica, 17(4), 64-76.

[4]. Chow, T., \& Cao, D. B. (2008). A survey study of critical success factors in agile software projects. Journal of systems and software, 81(6), 961971.

[5]. Hoegl, M., Parboteeah, K. P., \& Gemuenden, H. G. (2003). When teamwork really matters: task innovativeness as a moderator of the teamworkperformance relationship in software development projects. Journal of Engineering and Technology Management, 20(4), 281-302.

[6]. Strode, D. E., Huff, S. L., Hope, B., \& Link, S. (2012). Coordination in co-located agile software development projects. Journal of Systems and Software, 85(6), 1222-1238.

[7]. Nerur, S., \& Balijepally, V. (2007). Theoretical reflections on agile development methodologies. Communications of the ACM, 50(3), 79-83.
[8]. Abd El Hameed, T., Latif, M. A. E., \& Kholief, S. (2016). Identify and classify critical success factor of agile software development methodology using mind map. IJACSA) International Journal of Advanced Computer Science and Applications, 7(5).

[9]. Qureshi, M. R. J., \& Hussain, S. A. (2008). An adaptive software development process model. Advances in Engineering Software,39(8), 654-658.

[10]. Boehm, B., \& Turner, R. (2003). Balancing agility and discipline: A guide for the perplexed. AddisonWesley Professional.

[11]. Beck, K., Beedle, M., Van Bennekum, A., Cockburn, A., Cunningham, W., Fowler, M., ... \& Thomas, D. (2001). Manifesto for agile software development. Retrieved from: http://agilemanifesto.org/ [accessed: 10 June 2021].

[12]. Moe, N. B., Dingsøyr, T., \& Dybå, T. (2008, March). Understanding self-organizing teams in agile software development. In 19th australian conference on software engineering (aswec 2008) (pp. 76-85). IEEE.

[13]. Katz, R. (1982). The effects of group longevity on project communication and performance. Administrative science quarterly, 81104.

[14]. Malone, T. W., \& Crowston, K. (1994). The interdisciplinary study of coordination. $A C M$ Computing Surveys (CSUR), 26(1), 87-119.

[15]. Tannenbaum, S. I., Beard, R. L., \& Salas, E. (1992). Team building and its influence on team effectiveness: An examination of conceptual and empirical developments. In Advances in psychology (Vol. 82, pp. 117-153). North-Holland.

[16]. Larson Jr, J. R., \& Schaumann, L. J. (1993). Group goals, group coordination, and group member motivation. Human Performance, 6(1), 49-69.

[17]. Brannick, M. T., Prince, A., Prince, C., \& Salas, E. (1995). The measurement of team process. Human Factors, 37(3), 641-651.

[18]. Seers, A. (1989). Team-member exchange quality: A new construct for role-making research. Organizational behavior and human decision processes, 43(1), 118-135.

[19]. Levine, J. M., \& Moreland, R. L. (1990). Progress in small group research. Annual review of psychology, 41(1), 585-634. 